\title{
黒鉛結晶の熱澎脹について
}

\author{
山口大学工学部 松 山 英 太 郎
}

\section{On the Thermal Expansion of Graphite}

By Eitaro Matuyama

(Faculty of Engineering, Yamaguchi University, Ube)

c-dimensions of Ceylon graphite have been measured by $\mathrm{X}$-ray diffraction method in the range $25-800^{\circ} \mathrm{C}$ with a camera specially designed for this purpose. The diameter of the camera is $24 \mathrm{~cm}$, NiK $\alpha_{1}$ rays being used for 0008 line. The shifts of the line by temperature rise are fairly large and about $4 \mathrm{~mm}$ per $100^{\circ} \mathrm{C}$, which permit four or more diffracted lines at different temperatures to be photographed on a fixed film through a movable aperture. The changes of the c-dimensions are determined from the records obtained in this way.

An empirical formula of the c-dimensions as a function of temperature and a graphic chart plotting the measured points together with the points obtained by other authors are presented.

概 要

黒鉛結晶は異方性の異常に大きい結晶であつて 熱膨脹, 熱伝導, 硬度, 酸化速度, 電気伝導 ${ }^{1)}$ そ の他の電磁気的性質等が層面 ( $\mathrm{ab}$ 軸面) とそれ と直角方向 (c 軸) について測定されるとともに 理論的, とくに最近では量子力学的研究妇数多く 行われて注目すべき結果が得られているが，満足 に測定できる大きさの単結晶が活とんど得られな いことは実験上の大きな障害であつて，そのため 測定值はオーダー位しか信頼されない場合さえあ る。たとえば電気伝導度については，Krishnan と Ganguli ${ }^{2)}$ および Dutta ${ }^{3)}$ の测定ではa軸方 向には $\mathrm{c}$ 軸方向より 100 倍まども大きい值を得て いるが，Primak ${ }^{4}$ の測定結果ではそれほどの差 はなく5 倍程度となつている。この実験には特別 に完全な結晶が用いられたが；その大きさは1.5 $\mathrm{mm}$, 厚さは $0.1 \mathrm{~mm}$ に過ぎない。また，やわら かいので取披に細心の注意が払われている。残念 ながら大きい単結晶の製作はまだ試みられず，一 般に炭素は $3000^{\circ} \mathrm{C}$ 程度の高温度で黒鉛化されて も結晶はな打多少不完全であつて，加えて低温 度で鉄が凝固する時析出する Kish がもつと天 然物に近いようこである5。

熱膨脹については Erfling ${ }^{6)}$ は小結晶をならべ て板状とれて㱏びを光学的に測定しているがX線 的結果とは数倍の差がある。X線回折法によると
試料は粉末でよく, 結晶格子の大きさの測定精度 の限度は $10^{-5}$ 程度 $^{78)}$ である。この方法は初め 金属の機械的歪の測定 ${ }^{9}$ に利用されたのであるが 試料を電気炉中に加熱するとそのまま熱膨脹計と なる。しかし最高の精度を発揮するには相当の困 難をともなう。棒状試料を用いる留通の熱膨脹計 では密閉された管状電気炉中の温度が一ような部 分に試料を置き熱電対を用いて安全にその温度が 測定されるのであるが，X線回折カメラ中に大る 電気炻では，まず，その長さと大きさが制限され る。乙してもつと耂大切な炉の中心部に $\mathrm{X}$ 線を通 過させる二つの穴と回折線の出る空をあけねばな らない。実際炉の中心の試料の位置から見た空の 立体角はかなり大で, そのため温度の均一さは破 られる。な打炉がさいから熱電対の金属線を通 じての冷却が割合に大きくなる恐れがある ${ }^{10)}$ 。金 属のようなX線吸収率の大きいものでは直径 $1 \mathrm{~mm}$ の試料を用いても実際はごく表面の層から反身さ れるだげあるから回折線はシャープであるが， 黒鉛では $1 \mathrm{~mm}$ 程度の深さのところからも反射し てくるので線の巾は試料の太さと同程度となり， その位置を $0.01 \mathrm{~mm}$ 程度に決定することはかな り困難となる。

X線的測定の古い文献にはふれないことにす る。セイロン黒鉛につき室温と $800^{\circ} \mathrm{C}$ の間で行 つた Nelson と Riley ${ }^{11)}$ の測定はもつとも信頼 すべきものと思われる。そのカメラは Cavendish 
研究所の Bragg の実験室でしばしば精密測定に 用いられたもので，カメラの定数については十分 検定が行われており，また温度測定では純金属を 試料としその融点を直視またはX $\mathrm{X}$ 線回折により確 認して熱電対を補正するもつとも確実な方法がと られている(2)。

Riley ${ }^{13)}$ はまた熱力学的計算を行つている。黑 鉛の $\mathrm{c}$ と a 軸方向とでは弾性係数に大差があるか ら Debye の特性温度もそれぞれ $760^{\circ} \mathrm{C}, 2280^{\circ} \mathrm{C}$ と大きく開いてくる。したがつて $700^{\circ} \mathrm{C}$ 付近で はもつぱら $\mathrm{c}$ 軸方向の振動にエネルギーが吸収さ れてこの方に延びる。この結果横の収縮が a 軸 方向に起ることになる。

測定の結果はcの大きさは温度とともに放物線 的に増加し，したがつて膨韭係数は温度に比例し て増すことになるが $200^{\circ} \mathrm{C}$ と $400^{\circ} \mathrm{C}$ の間では ほ济一定となつている。またaの值は $400^{\circ} \mathrm{C}$ で 極小值を示しており理論と一致する傾向が出てい る。

Walker, Mc Kinstry, Wright ${ }^{14)}$ は Norelco $\mathrm{X}$ 線回折装置に電気炉と. 低温装置とを付して $-196^{\circ} \mathrm{C}$ より $1118^{\circ} \mathrm{C}$ の範囲にわたつて黒鉛化 カーボンの層間隔を測定している。特にふんい気 の影響に注目し $\mathrm{N}_{2}, \mathrm{O}_{2}, \mathrm{CO}_{2}, \mathrm{Ar}$ で試みているが, その影響はみられない。回折角 $2 \theta$ は $54^{\circ}$ であ まり大きくない。回折線の币も約 $1^{\circ}$ であって天 然黒鉛に比べると太いがガイガ管による自記記録 装置のせいで測定誤差は割合に小さい。

筆者はさきに特別に作つた高温 $\mathrm{X}$ 線カメラを用 いてセイロン黒鉛試料をカーボン管中に加熱して $1000^{\circ} \mathrm{C}$ と $1800^{\circ} \mathrm{C}$ の間で aと $\mathrm{c}$ の值を測定し た ${ }^{15)}$ 。a の熱膨脹係数は $\mathrm{c}$ のほ泳 30 分の 1 であ つた。Nelson, Riley の結果では $400^{\circ} \mathrm{C}$ で一た ん極小值をとり，これから $800^{\circ} \mathrm{C}$ まで上昇傾向 をとるが，この装置では明瞭にaの膨脹による回

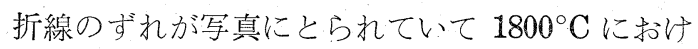
る測定点はちょうど Nelson, Riley の曲線の超 長にのつている。

筆者は今回多少特長のある黒鉛専用の高温 $\mathrm{X}$ 線 カメラを作つて室温と $800^{\circ} \mathrm{C}$ の間で $\mathrm{c}$ の值を測 定した。この結果と上に記した測定結果とを合せ でわりにグラフで示すことにする。

\section{高温 $\mathbf{X}$ 線决}

粉末回折法では Bragg 角 $\theta$ が $90^{\circ}$ に近づく とともに次の式にしたがつて角の変化 $\Delta \theta$ は面間 隔の変化に比して大きくなる。

$$
\Delta \theta / \frac{\Delta d}{d}=-\tan \theta
$$

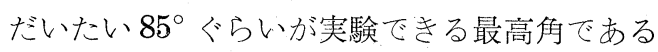
が，利用できる特性 $\mathrm{X}$ 線の波長の種類がいくらも ないので希望通りにはなり難い。 Nelson, Riley は $\mathrm{MnK} \alpha$ 線の 0006 の面よりの反射を用いて $\mathrm{c}$ の值を決定したが， $\theta$ は約 $70^{\circ}$ であつた。これは 同時に 2000 面の反射より $\mathrm{a}$ の值を得るために選 定されたものであるが，eだけであると $\mathrm{NiK} \alpha$ 線の 0008 の面よりの反射它利用すると $\theta$ は $81^{\circ}$ となり $\Delta \theta$ は約 2 倍になる。しかし面指数が大き いので反射強度は小さく，なお高温における強さ の減少が著しい。高温に㧊いて温度の変動が $1^{\circ}$ 以下にとどまるように調節を続けねばならないの で X線照射時間はなるべく短かいことが望まれ る。それで前実験 ${ }^{16)} に$ 用いたのと同じ大きさのプ レスした円板試料を用いた。結晶は板面にほほ平 行に配向しているので層面からの反射だけが強め られてこれと直角な面からの反射はかす加現れ るだけである。

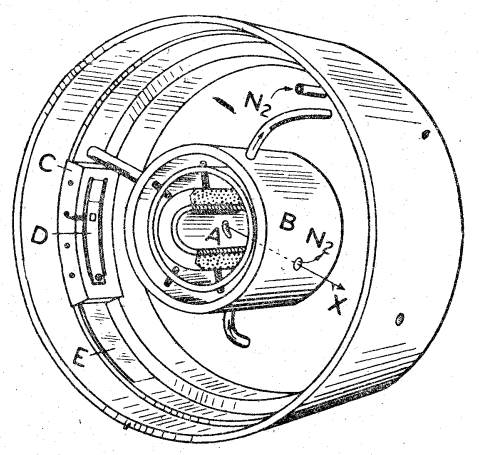

Fig. 1. Interior of high temperature Debye-Scherrer camera, showing furnace (A) and aperture (D) for isolating 0008 line.

カメラの構造を Fig. 1 に示す。鋳鋼製であつ てフイルム面の直径は $24 \mathrm{~cm}$ である。0008の線 の $\mathrm{K} \alpha_{1}$ と $\mathrm{K} \alpha_{2}$ とは $4 \mathrm{~mm}$ の間隔に開いて写 り， $100^{\circ} \mathrm{C}$ 温度上昇によるこの線のずれもほぼ $4 \mathrm{~mm}$ である。炉の温度を $200^{\circ} \mathrm{C}$ づつ上げて各 
温度における $\mathrm{K} \alpha_{1}$ 線の回折線だけを同一フイル ム上に撮影する。 $\mathrm{E}$ はフイルムで小カセッテ Cの 下端より左に向つて挿入してある。 $\mathrm{D}$ は露出用空 でその位置は指針とカセッテCの前面にある度盛 板とで読みとれる。炉の温度を変え, 露出空を計 算した角において逐次露出を行なう。

電気炉はカメラの直径で制限され，な打水冷筒 などを中間に扮かね齐ばならないのであるが，なる べく一般の管状電気炉に近いものを入れることを 考えた。

$\mathrm{A}$ は高アルミナ円筒で普通の $\mathrm{A}$ 質耐火管の 2 倍 以上の熱伝導率を持つている。その内径は $24 \mathrm{~mm}$, 長さは $100 \mathrm{~mm}$, 回折 $\mathrm{X}$ 線射出スロットの币は $2 \mathrm{~mm}$ で必要な範囲にだけ開けてあり，一般用の ように $180^{\circ}$ には広げてない。別に直進 $\mathrm{X}$ 線の 出る穴がある。材質が硬いので工作に時間がかか つた。この上に電熱線を巻き内径 $45 \mathrm{~mm}$ の耐火 円筒中に入れ，中間に陶土が充してある。Bは $1 \mathrm{~mm}$ 黄銅板製の水冷円筒で冷却水は矢のとおり 順環する。炉の両端は厚さ $15 \mathrm{~mm}$ のアスベスト 板でせんがしてある。 pt 熱電対の接点を炉の中 央の試料の直前に执いて針金は 1 巻きした後焒の 中央をとおり前方の口より出て炉の外側を趈つて 後面よりカメラ外に出る。この熱電対は北辰検定 表付熱電対と電位差計を用いて補正した。電気炉 は $2.5 \mathrm{k} . W$. 定電圧変圧器を電源とし手動調節に より温度変動は $800^{\circ} \mathrm{C}$ に拈いても $1^{\circ} \mathrm{C}$ 以下に保 つた。

試料の温度变化 $1^{\circ}$ によつて回折線は約 0.04 $\mathrm{mm}$ ずれるから，温度の変動はそれ以下にせね ばならない。な㧍カメラ全体を一定温度に保つた めに, Fig. 1 のカメラの後面の板は全面冷却水 に接している。また前面の盖には銅管がハンダづ けしてあつて冷却水はこれを通過後後面をへて電 気炉の外の水冷円筒に入る。この水はあらかじめ 電熱により $25^{\circ} \mathrm{C}$ 一定に保つた。

試料は $20 \mathrm{mg}$ の $\mathrm{HCl}$ および $\mathrm{HF}$ 処理したセ イロン黒鉛粉を $40 \mathrm{~kg}$ の力で接着剂を加えず直 径 $6 \mathrm{~mm}$ の円板に成形したもので愿さは約 $1 \mathrm{~mm}$ であつた。

Fig. 2 に試料の支持棒を示す。透明石英で作 り，左端く形板上に試料の黒鉛板をモリブデン板 のクリップで止める。 Fig. 1 のカメラの後方に

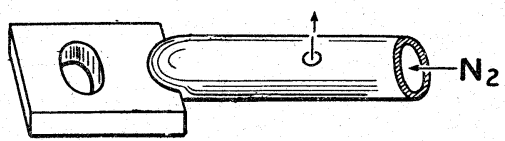

Fig. 2. Specimen holder, made of fused silica.

図には現れていないが，この棒を与える迴転装置 があり，センターを合せ試料を反射角において撮 影中は $10^{\circ}$ の振巾で振動させる。この振動は小形 モータの逆転により自動的に行われる。

酸化を防ぐため炉の中に $\mathrm{N}_{2}$ ガスを充たした。 99.5\% 純度のボンべ入りガスを熱銅粉中をとお して酸素を除いた後, 試料棒の右端より入れる。 炉の付近に二つの穴があり，一つは直接炉の中に 他の穴は炉の外側にガスを出し，炉の外側を廻つ て回折X線の出る㝕に通じる。電気炉の水冷円筒 の回折 $\mathrm{X}$ 線の出る空には $0.005 \mathrm{~mm}$ の $\mathrm{Al}$ 箔が はつてあり，炉の輻射を防ぎ $\mathrm{N}_{2}$ ガスの対流を制 限する。

カメラの検定は黒鉛試料中に少量の水晶粉末を まぜ水晶の精密面間隔の值を用いて行つた。各フ イルムには $25^{\circ}$ において黒鉛 0.008 の線を入れ この位置に沶いて $c=6.69600$ とした。この值は Nelson, Riley の実験式に $25^{\circ} \mathrm{C}$ を入れて計算 したものである。

\section{測 定 結 果}

$25^{\circ}$ と $100^{\circ}$ より $800^{\circ}$ までの $100^{\circ}$ おきの温 度で測定した。最小自乗法で求めた実験式は次の とおりである。

$$
c=6.6918+164.48 \times 10^{-6} t+20.45 \times 10^{-9} t^{2}
$$

$K X$.

$$
\text { 公算誤差土 } 3.6 \times 10^{-4}
$$

これを用いて熱膨脹率を計算すると,

$$
\frac{1}{c} \frac{d c}{d t}=24.58 \times 10^{-6}+5.10^{-9} t
$$

Fig. 3 に上に記した諸結果をまとめて示す。 図の縦軸には $\frac{c}{2} に$ 相当する層間隔がとつてあつ て，単位は $\AA$ または $K X$ であり原著者のまま記 入してある。

A は Walker 等 ${ }^{14)}$ の曲線である。原著には 測定点に炉中の気体 $\mathrm{O}_{2}, \mathrm{~N}_{2}, \mathrm{CO}_{2}, \mathrm{Ar}$ の差別がつ けてあるが，ここでは全部円で記入してある。層 間隔の単位は 凡̊である。 


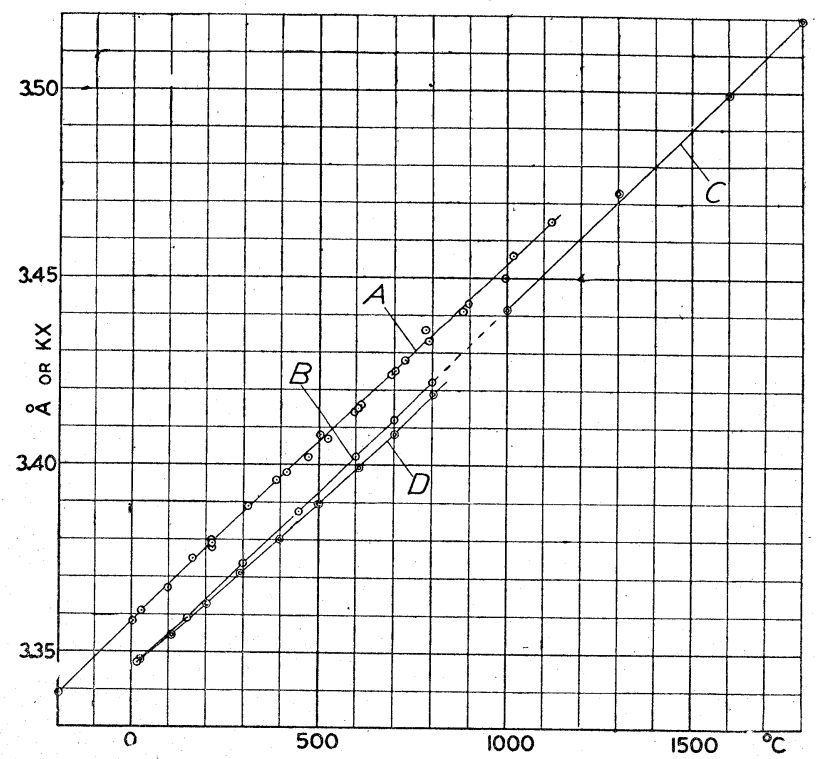

Fig. 3. Layer spacings as a function of temperature.
A. Walker, et al. Graphitized carbon.
B. Nelson, Riley, Ceylon graphite.
C. Matuyama, Ceylon graphite.
D. Matuyama, Ceylon graphite.

B は Nelson, Riley ${ }^{11)}$ の曲線である。A曲線 よりかなり低い。層間隔の単位は $K X$ であつて Bragg のすすめる $K X$ より $え$ え換算係数 1,00202 を用いて換算すると A, B 兩曲線の間隔 は約 $1 / 3$ に減少する。人造黒鉛では層間隔が天然 黒鉛より大きいが熱膨脹係数は等しいことがわか る。

C は筆者 $^{15)}$ によるBの延長曲線である。

Dは今回の測定である。測定点に公算誤差は大 きくないが，組織的誤差があるようにみえる。恐 らくその原因は熱電対温度と試料温度との差にあ つて，主としてガスの対流によるものと思われ る。

$300^{\circ}$ と $500^{\circ} \mathrm{C}$ の間で測定値は計算值より少し 小さく出ている。これは Nelson, Riley と同一 傾向であるがこれより計算した熱膨脹係数は彼等 のようにこの間で一定とはならなかつた。

終りに研究用黒鉛のご援助を戴いている，日新 黑鉛耐火株式会社社長原幾久民に謝意を表する。

$$
\text { 参 考 文 献 }
$$

1) Grisdale, Pflster, van Roosbroeck, Bell Syst.

Tech. J. 30, 271 (1951).
2) K. S. Krishnan, N. Ganguli, Nature 144, 667 (1939).

3) A. K. Dutta, Phys. Rev. 90,187 (1953).

4) W. Primak. Rev. 103, 544 (1956).

5) P. L. Walker, Jun., George Imperial, Nature 180, 1185 (1957). L. M. Foster, G. Long, H. C. Stump, Amer. Mineralogist 43, $285^{\circ}$ (1958).

6) H. D. Enfling, Ann. Phys. 34, 136 (1935).

7) M. E. Straumanis, E. Z. Aka, Amer. Chem. Soc. 73, 5644 (1952).

8) H. Weyerer, Z. angew. Phys. 8, 202 (1956).

9) R. Glocker, Materiaprufüng mit Röntgenstrahlen, p. 304 (1936).

10）野村昭一郎，応物， 26,381 , 昭 32 .

11) J. B. Nelson, D. P. Riley, Proc. Phys. Soc. Lond. 57, 477 (1945).

12) Z.S. Basinski, J. W. Christian, Proc. Roy. Soc. A. 223, 554 (1954).

13) D. P. Riley, Proc. Phys. Soc. Lond. 57, 486 (1945).

14) P. L. Walker, Jr., H.A. McKinstry, C.C.

Wright, Ind. Eng. Chem. 45, 1711 (1953).

15) E. Matuyama, J. Sci. Instr. 32,229 (1955).

16) E. Matuyama, Nature 176, 1459 (1956). 